УДК 341.63

DOI https://doi.org/10.32837/yuv.v0i1.1618

В. Нагнибіда,

кандидат юридичних наук, доцент,

доцент кафедри міжнародного та європейського права

Хмельницького університету управління та права

імені Леоніда Юзькова

\title{
ВИКОНУВАНІСТЬ РІШЕННЯ МІЖНАРОДНОГО КОМЕРЦІЙНОГО АРБІТРАЖУ У СВІТЛІ ТЕОРІЇ ТА ПРАКТИКИ ПРАВОЗАСТОСУВАННЯ
}

Як відомо, метою будь-якого юрисдикційного процесу, пов'язаного із захистом прав і законних інтересів учасників цивільного обороту, є вирішення спору та його виконання на основі винесеного суб'єктом правозастосування рішення. Не $є$ винятком i cфера міжнародного комерційного арбітражу, де постановлення арбітражного рішення у спорі між учасниками міжнародного комерційного обороту $є$ кінцевою метою арбітражного розгляду та водночас повинно слугувати гарантією подальшого виконання такого рішення. I якщо стосовно рішень судових органів уже сам по собі факт існування судового процесу спонукає учасників спору зважати на судовий розгляд і перспективу виконання такого рішення органами примусового виконання судових рішень, то у разі розгляду спору міжнародними комерційними арбітражами як недержавними інститутами розгляду і вирішення міжнародних комерційних спорів часто сторони та, як це не прикро, подекуди i їні радники не надають належного значення арбітражному розгляду і відповідно не оцінюють усю серйозність ситуації та їі юридичних наслідків.

3 боку міжнародного комерційного арбітражу, а точніше складу арбітражу (арбітражного трибуналу) ситуація виглядає таким чином, що, встановивши свою компетенцію на розгляд i вирішення спору, арбітр (арбітри) на основі наданих сторонами доказів, фактичних обставин і положень застосовуваного права мають вирішити спір шляхом постановлення вмотивованого рішення, яке б могло бути приведене до виконання стороною, на користь якої воно винесено. Зважаючи на наявність міжнародного елементу у справах, що вирішуються міжнародними комерційними арбітражами, а також присутність однієї компанії та / або їі майна у кількох юрисдикціях, сучасний арбітраж часто змушений оцінювати перспективи виконання постановлюваного рішення. Попри те, що правом місця арбітражу встановлюються мінімальні вимоги до чинності арбітражних рішень, все ж склад арбітражу має не випускати з поля зору і право країни, в якій таке рішення буде виконуватися, якщо таке право чи країну можна ідентифікувати на етапі розгляду спору.

У нашій статті, не вдаючись у проблеми обов'язку арбітрів забезпечити виконуваність рішення, ми розглянемо мінімальні стандарти чинності та виконуваності рішення міжнародного комерційного арбітражу, встановлені у більшості провідних арбітражних юрисдикцій. Окремі питання з цієі проблематики були предметом досліджень таких вчених і фахівців у галузі арбітражу, як Л.Ф. Винокурова, Т.Г. Захарченко, О.Д. Крупчан, М.М. Мальський, О.С. Перепелинська, І.Г. Побірченко, Ю.Д. Притика, М.Ф. Селівон, Т.В. Сліпачук, Г.А. Цірат, Ю.С. Черних та ін. Водночас низка аспектів усе ще зали- 
шаються поза увагою теоретиків і практиків, а тому іх актуальність лише зростає. Особливо це стосується питань вмотивованості арбітражних рішень, порядку їх підписання, направлення сторонам тощо.

Одним із завдань арбітражного розгляду і вирішення спорів є захист порушених, невизнаних чи оспорюваних прав та інтересів сторони. Звісно, такий захист повинен бути ефективним, тобто забезпечуватися справедливим, всебічним і своєчасним арбітражним розглядом з одного боку, а з іншого - правильністю та виконуваністю рішення, постановленого за результатами такого розгляду.

Постановлення рішення складом арбітражу є останньою стадією правозастосування, і від його якості значною мірою залежить можливість виконання та захисту прав та інтересів сторін спору. Згадувана «якість» арбітражного рішення за загальним правилом оцінюється з погляду його відповідності вимогам, встановленим правом країни місця арбітражу (lex arbitri), та регламентом, що застосовується до вирішення спору. Такі вимоги стосуються трьох аспектів: 1) змісту рішення; 2) форми рішення; 3) порядку (процедури) постановлення рішення.

Міжнародними актами, як і арбітражними законодавствами більшості країн питання вимог щодо змісту арбітражних рішень врегульовані у найбільш загальних формулюваннях. Це пов'язано з тим, що арбітраж як гнучка форма альтернативного вирішення спорів не повинен бути «зарегульованим», подібно до вимог, які встановлені стосовно рішень державних судів у національних законодавствах. Крім цього, через наявність іноземного елементу, застосування різних систем права (які врегульовують сутність спору, арбітражний розгляд, здатність сторін до укладення арбітражної угоди тощо), а також беручи до уваги відмінності юрисдикцій, підходів до юридичної техніки, внутрішні вимоги національного права та регламентів постійно діючих арбітражних інсти- тутів і правил, за якими відбувається процедура ad hoc арбітражу, досягнути єдності у вимогах до змісту арбітражних рішень досить складно. До того ж, встановлення вимог до арбітражних рішень на рівні міжнародних актів могло б бути сприйняте державами як «нав'язування» та створення додаткових підстав для невідповідності та суперечності постановлюваних арбітражами рішень вимогам міжнародних актів.

У зв'язку з цим у частині вимог до змісту арбітражних рішень міжнародні акти містять лише вимогу, що такі рішення повинні бути вмотивованими, якщо сторонами не передбачено інше (ст. VIII Європейської конвенції 1961 р. [1], ст. 31 (2) Типового закону ЮНСІТРАЛ [2], ст. 31 (2). Вимога щодо вмотивованості сформульована у вказаних актах у формі презумпції. Тому постановлення невмотивованого рішення допускається лише у двох випадках: 1) коли сторони погодили постановлення такого рішення («у справах, які вимагають постановлення швидкого рішення, або з питань встановлення відповідності якості товарів, послуг певним визначеним вимогам, стандартам, постановлення рішення «на узгоджених умовах» тощо» [3, с. 642]) або 2) коли сторони обрали арбітражну процедуру, котра передбачає, що рішення може бути невмотивованим, і жодна зі сторін не вимагала, щоб таке рішення було вмотивованим (ст. VIII (b) Європейської конвенції 1961 р.). В останньому випадку Європейська конвенція 1961 р. також передбачає, що право сторони вимагати постановлення вмотивованого рішення може бути реалізованим або до закінчення усного розгляду справу справи, а у разі, коли такий розгляд не проводився - до моменту складання арбітражного рішення. Зважаючи на те, що і перший, і другий випадки можуть бути реалізовані лише на основі погодження (домовленості) сторін, за якою сторони добровільно погоджують прийняття невмотивова- 
ного рішення або обирають відповідну арбітражну процедуру, якою передбачається постановлення такого рішення, на практиці така домовленість між сторонами допускається як у прямій, так і в опосередкованій формі (explicitly or implicitly) [4; 5, с. 534]. Опосередкований характер матиме також згода сторін на застосування арбітражної процедури в порядку ст. VIII (b) Європейської конвенції 1961 р., адже сторони, погоджуючись на таку процедуру, не дають прямої згоди на постановлення невмотивованого арбітражного рішення. Судова практика виходить із того, що згода на застосування такого регламенту або правил арбітражного розгляду передбачає і згоду (implicit consent) на постановлення немотивованого арбітражного рішення [6].

Водночас слід зробити окреме застереження щодо питання реалізаціi права сторони вимагати постановлення вмотивованого рішення до закінчення усного розгляду справу справи, а у разі, коли такий розгляд не проводився - до моменту складання арбітражного рішення, передбаченого ст. VIII (b) Європейської конвенції 1961 р. В англійському та французькому текстах цієї частини статті міститься одна невелика, але досить важлива розбіжність. Французький текст передбачає, що вимога сторони (чи сторін) про постановлення вмотивованого рішення повинно бути зроблене прямо, явно (expressément), тоді як англійський текст такої вимоги не містить. Цікаво, що російський текст, який поряд із французьким та англійським є автентичним, використовує формулювання «если при этом ни одна из сторон не потребовала особо», що за контекстом також варто тлумачити як пряму, явну вимогу щодо постановлення мотивованого арбітражного рішення [1]. Таким чином, виходячи 3 офіційних текстів Конвенціï французькою та російською мовами, останні передбачають пряме, явне звернення сторін або сторони з вимогою про постановлення вмотивованого рішення. Відповідно до англійського тексту таке звернення може бути і неявним, тобто сформульованим непрямо (implicitly).

Незважаючи на відсутність вимог до змісту арбітражного рішення у міжнародних актах, окрім вимоги щодо його вмотивованості, у праві окремих країн та арбітражних регламентах із цього приводу часто містяться більш детальні положення. Наприклад, у праві Голландії додатково передбачено необхідність зазначення імен та адрес арбітра (арбітрів) і сторін (ст. 1057(4) (a), (b) ЦПК Нідерландів [7]).

Питання форми арбітражних рішень як і питання форми не має детального регулювання у міжнародних актах, окрім ст. 31 Типового закону ЮНСИТРАЛ, якою передбачено, що арбітражне рішення повинно бути винесене в письмовій формі та підписане арбітром чи арбітрами. У арбітражних розглядах з більш, ніж одним арбітром, достатньо підписів більшості усіх членів складу арбітражу, із зазначенням причини відсутності відсутнього підпису (ст. 31(1) Типового закону ЮНСІТРАЛ). Крім цього, в арбітражному рішенні повинні зазначатися його даma $i$ мiсuе арбітражу (ст. 31(3) Типового закону ЮНСІТРАЛ), як місце, погоджене у відповідності зі ст. 20(1) Типового закону ЮНСІТРАЛ самими сторонами або ж визначене складом арбітражу 3 урахуванням обставин справи, в т. ч. з урахуванням його зручності для сторін. Будь-яких інших вимог до формальних аспектів арбітражного рішення Типовий закон ЮНСІТРАЛ не містить ${ }^{1}$. Письмова форма, дата і місце арбітражу є очевидними вимогами до арбітражного рішення. Стосовно обов'язковості зазначення місця арбітражу відзначимо, що під «місцем арбітражу» (place or seat of arbitration) тут мається на увазі вказівка на країну, відповідно до процесуального права якої здійснювалася арбітражна процедура [10, с. 867-868; 11, c. 112-119] i за правом якої оцінюватиметься чинність арбітражного рішення та подальша можливість його виконання у світлі вимог Нью-Йоркської конвенції 1958 р. 
[12]. В арбітражному середовищі це право відоме також як lex arbitri. Зважаючи на це наявність в арбітражному рішенні вказівки на місце арбітражу як юридичного критерію прив'язки арбітражного рішення до процесуального права певної країни є надзвичайно важливим елементом, за яким оцінюється чинність арбітражного рішення та можливість його виконання.

Попри відсутність вимог до форми арбітражного рішення у міжнародних актах, окрім вказаних вимог до письмової форми, підписів арбітрів, дати і місця арбітражу, у праві окремих країн та арбітражних регламентах із цього приводу часто містяться більш детальні положення. Наприклад, згідно із правом Нідерландів передбачено обов'язкову передачу остаточного або часткового арбітражного рішення на зберігання в секретаріат районного суду, в якому знаходиться місце арбітражу (ст. 1058(1) (b) ЦПК Нідерландів).

Порядок (процедура) постановлення рішення передбачає, що у разі, коли арбітражний розгляд здійснюється більш, ніж одним арбітром, тобто колегіально, рішення постановлюється більшістю складу арбітражу, крім випадків, коли сторони не домовилися про інше. Вказане правило міститься в Типовому законі ЮНСТІРАЛ (ст. 29) та було імплементовано у внутрішньому арбітражному законодавстві багатьох країн, законодавства яких імплементували положення Типового закону ЮНСТІРАЛ. Крім цього, в частині процедури також передбачається обов'язковість направлення сторонам арбітражного рішення, підписаного арбітрами (ст. 31(4) Типового закону ЮНСІТРАЛ).
Не вдаючись у питання вимог до різних видів арбітражних рішень, відзначимо, що приведені вимоги щодо змісту, форми та процедури постановлення арбітражних рішень стосуються передусім остаточних рішень у справі. Водночас окремо слід відзначити, що аналогічні вимоги повинні виконуватися і при постановленні рішень на узгоджених умовах. Попри те, що такі рішення на практиці постановлюються зазвичай напередодні або ж у процесі арбітражного розгляду [13, с. 31], за своїм змістом і формою вони за відсутності застережень про інше (або спеціальних положень) також повинні відповідати вимогам встановленим щодо арбітражних рішень у lex arbitri. Практиці відомі випадки, коли постановлені арбітражні рішення на узгоджених умовах скасовувалися на тій підставі, що вони не відповідали умовам, встановленим до арбітражних рішень застосовуваним правом країни місця арбітражу [14]. Крім цього, у праві зарубіжних країн щодо обов'язковості закріплення рішень на узгоджених умовах можуть міститися вимоги. Наприклад, щодо постановлення 3 дотриманням вимог, встановлених до арбітражних рішень, з обов'язковою наявністю підписів сторін (ст. 1069 ЦПК Нідерландів).

Підсумовуючи, відзначимо, що склад арбітражу повинен вжити усіх заходів, аби постановити рішення, яке повинне: 1) відповідати вимогам, встановленим lex arbitri; 2) бути вмотивованим i 3) виконуваним. Зазначені вимоги до рішення арбітражу у переважній більшості правопорядків та арбітражних Регламентів закріплені нормативно. Водночас щодо обов'язку постановлення арбітражем саме виконуваного рішення

${ }^{1}$ Слід відзначити, що результати роботи першої робочої групи із розробки проекту Типового закону ЮНСІТРАЛ містили додатково ще одну вимогу стосовно необхідності реєстрації арбітражних рішень у державному або іншому реєстрі з метою надання йому чинності, у т. ч. на вимогу однієї зі сторін. Більш детально див.: Paragraph 108 of the Report of the Working Group on International Contract Practices on the Work of its Third Session A / CN.9/216 (New York, 16-26 February 1982) [8]. Не було відображено в остаточному тексті Типового закону ЮНСІТРАЛ і жваво обговорюваних у робочих групах положень щодо окремої думки арбітра (dissenting opinion), порядку їі підписання арбітром і наявності в такому разі підпису на тексті самого арбітражного рішення. див.: Art. 31 para. 2 of the Analytical Commentary on Draft Text of a Model Law on International Commercial Arbitration : Report of the Secretary-General A CN. 9 / 264. (25 March 1985) [9] 


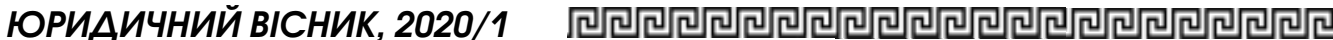

питання залишається дискусійним як у теорії, так і на практиці, а тому має бути детально розглянуте та досліджене у подальших наукових роботах.

У статті досліджуються теоретичні та практичні аспекти виконання рішень міжнародних комериійних арбітражів. У вступі обтрунтовується актуальність обраної теми дослідження. Зокрема, автором доводиться, щзо постановлення арбітражного рішення у спорі між учасниками міннародного комериійного обороту є кінцевою метою арбітражного розгляду, як $i$ при вирішенні спорів у судах. Така мета повинна слугувати гарантією подальшого виконання арбітражного рішення. Саме тому після встановлення компетениіі на розгляд $i$ вирішення спору арбітр (арбітри) на основі наданих сторонами доказів, фактичних обставин $і$ положень застосовуваного права мають вирішити спір иляхом постановлення вмотивованого рішення, яке б могло бути приведене до виконання стороною, на користь якої воно винесено, у т. ч. у примусовому порядку. 3 огляду на ие видається актуальним завдання наукового осмислення вимог до арбітражних рішень їх виконуваності з погляду перспектив захисту прав та інтересів учасників міжнародного комериійного обороту.

Дослідження побудоване через призму вивчення вимог до арбітражних рішень, а саме вимог до змісту, форми та порядку постановлення таких рішень. Досліджуються питання вмотивованості рішень та обов'язку складу арбітражу постановлення вмотивованого рішення, а також випадки, коли допускається постановлення рішення без наведення обтрунтування. Окремо досліджуються питання формальних вимог до арбітражних рішень: постановлення у письмовій формі, наявності дати, підпису арбітрів $i$ зазначення місия арбітражу. Окремо звертається увага на питання місия арбітражу. Акцентується увага на тому, що иее є юридичний критерій, за яким оцінюється чинність арбітражного рішення. В арбітражному середовищі ие право відоме також як lex arbitri. Окремо розглядаються вимоги до порядку постановлення рішень, прийняття їх більшістю від складу арбітражу та направлення сторонам спору.

На підставі проведеного дослідження зроблено висновок про те, що склад арбітражу повинен вживати усіх розумних $i$ необхідних заходів, щоб постановити рішення, яке б відповідало вимогам, встановленим правом місия арбітражу, було вмотивованим $і$ виконуваним. Зазначені вимоги до рішення арбітражу у переважній більшості правопорядків та арбітражних Регламентів закріплені нормативно. У статті наводяться норми міжнародних актів і положення актів національного права, які обтрунтовують висновки автора.

Ключові слова: правозастосування, рішення арбітражу, склад арбітражу, виконуваність, вмотивованість, право місця арбітражу.

Nahnybida V. Enforceability of arbitral awards in the light of theory and practice of law application

The article explores the theoretical and practical aspects of the execution of international commercial arbitration awards. The introduction substantiates the relevance of the chosen research topic. In particular, the author argues that the ruling of an arbitration award in a dispute between participants in international commercial traffic is the ultimate purpose of arbitration, as in the settlement of disputes in the courts. Such a purpose should serve as a guarantee for the further execution of the arbitral award. That is why, after the competence to review and resolve the dispute has been established, the arbitrator(s), based on the evidence provided by the parties, the factual 
circumstances and the provisions of the applicable law, must resolve the dispute by issuing a reasoned decision that could be enforced by the party in favor of which it was rendered, including compulsory enforcement. In view of this, it seems urgent to scientifically comprehend the requirements for arbitration awards of their enforceability from the perspective of protection of rights and interests of participants of international commercial turnover.

The study is built through the lens of examining the requirements for arbitral awards, namely the content, form and order of ruling such decisions. The issues of decision justification and the obligation of arbitration to make a reasoned decision are investigated. Cases where a decision is allowed without justification. Formal requirements for arbitral awards are also examined separately: written decision, date indication, signature of arbitrators and indication of the place of arbitration. Special attention is paid to the issue of the place of arbitration. Attention is drawn to the fact that this is the legal criterion by which the validity of the arbitral award is evaluated. In an arbitration environment, this law is also known as lex arbitri. Requirements for the order of issuing decisions, their adoption by the majority of the arbitration panel and referral to the parties to the dispute are considered separately.

Based on the research, it was concluded that the arbitration panel should take all reasonable and necessary steps to rule an award that would meet the requirements established by the law of the place of arbitration, be reasoned and enforceable. These requirements for arbitration in the vast majority of legal systems and arbitration Rules are legally fixed. The article specifies the norms of international acts and the provisions of acts of national law that substantiate the author's conclusions.

Key words: law enforcement, arbitration award, arbitration panel, enforceability, justification, law of the place of the arbitration.

\section{Література}

1. European Convention on International Commercial Arbitration. Geneva, 21 April 1961 Treaty Collection. United Nations Organization. URL: https: / / treaties.un.org / doc / Treaties / 1964/01/19640107\% 20 02-01\%20AM/Ch_XXII_02p.pdf.

2. UNCITRAL Model Law on International Commercial Arbitration (with amendments as adopted in 2006). The United Nations Commission on International Trade Law. URL: https: / / www.uncitral.org / pdf / english / texts / arbitration/ml-arb/07-86998_Ebook.pdf.

3. Howard M. Holtzmann, Joseph E. Neuhaus A Guide to the UNCITRAL Model Law on International Commercial Arbitration: Legislative History and Commentary. The Hague: Kluwer Law and Taxation Publishers, 1995. 846 p.

4. Art. 31, para. 3 of the Analytical Commentary on Draft Text of a Model Law on International Commercial Arbitration: Report of the Secretary-General A / CN. 9 / 264. (25 March 1985). United Nations Commission on International Trade Law. URL: https: / / undocs.org / en / A / CN.9/ 264.

5. HascherD.T.Commentaryon the European Convention on International Commercial Arbitration of 1961. Yearbook Commercial Arbitration. 2011. Vol. XXXVI. P. 504-562. URL: $\quad$ https: / / wwer.arbitration-icca.org / media / 4 / 49305067580462 / media 113534204 360520hascher_commentary_on_the_european_ convention_1961.pdf.

6. Decision of 12 December 1975: Case of Provenda S.A v. Alimenta S.A and Geneva. Court of Justice (Switzerland). URL: http: / / newyorkconvention 1958.org / index. php?lvl=notice_display\&id $=559$.

7. Dutch Code of Civil Procedure Effective 1 October 2019. Book 4. Arbitration. URL: http:// wrw.dutchcivillaw.com / civilprocedureleg.htm.

8. Report of the Working Group on International Contract Practices on the Work of its Third Session A / CN.9 / 216 (New York, 16-26 February 1982). United Nations Commission on International Trade Law. URL: https: / / undocs.org / en/A/CN.9/216.

9. Art. 31, para 2 of the Analytical Commentary on Draft Text of a Model Law on International Commercial Arbitration : Report of the Secretary-General A / CN. 9 / 264. (25 March 1985). United Nations Commission on International Trade Law. URL: https: / / undocs.org/en/A/CN.9/264.

10. Varady T., Barcello J., Kroll S., Mehren Arthur T. International Commercial 


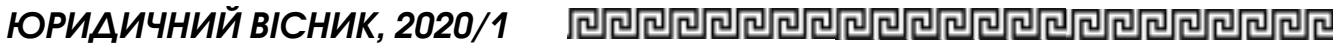

Arbitration: A Transnational Perspective. West Academic Publishing, 2015. 1293 p. 11. Scherer M. The Place or 'Seat' of Arbitration (Possibility, and / or Sometimes Necessity of its Transfer?) - Some Remarks on the Award in ICC Arbitration $n^{\circ} 10^{\prime} 623$. ASA Bulletin. 2003 № 1. P. 112-119.

12. Convention on the Recognition and Enforcement of Foreign Arbitral Awards (New York, 1958). United Nations Organization. URL: $\quad$ https: / / www.uncitral.org/pdf/ english/texts / arbitration / NY-conv/ NewYork-Convention-E.pdf.

13. Захватаев В.Н. Комментарии к мировой практике международного коммерческого арбитража. Кн. 2. Киев : Aлерта, 2015. 810 c.

14. Oberlandesgericht Frankfurt a. M., Germany, 20 Sch 01 / 02, 14 March 2003. URL: http://www.dis-arb.de/en/47/ datenbanken / rspr/olg-frankfurt-am-caseno-20-sch-01-02-date-2003-03-14-id240. 